\title{
KONTRIBUSI EKONOMI PEREMPUAN, TEKANAN EKONOMI, DAN KESEJAHTERAAN KELUARGA PADA KELUARGA NELAYAN DAN KELUARGA BURUH TANI BAWANG MERAH
}

\author{
Herien Puspitawati ${ }^{*}$, Artika Chandra Julian Putri , Anadia Titipani, \\ Muwakhidah Nur Khasanah
}

Departemen IImu Keluarga dan Konsumen, Fakultas Ekologi Manusia, Institut Pertanian Bogor, Bogor 16680, Indonesia

${ }^{*}$ E-mail: herien_puspitawati@email.com

\begin{abstract}
Abstrak
Sebagian besar petani dan nelayan di Indonesia memiliki keterbatasan dalam memenuhi kebutuhan ekonomi, sosial, serta standar kebutuhan lainnya. Keterbatasan tersebut menunjukkan rendahnya tingkat kesejahteraan keluarga. Penelitian ini bertujuan untuk menganalisis pengaruh karakteristik keluarga, kontribusi ekonomi perempuan, dan tekanan ekonomi terhadap kesejahteraan keluarga pada keluarga nelayan dan buruh tani bawang merah. Lokasi penelitian dilakukan pada dua lokasi yaitu di Kali Adem Muara Angke dan Desa Losari Lor, dengan contoh berjumlah 130 responden (60 istri nelayan dan 70 istri buruh tani bawang). Data yang dikumpulkan dalam penelitian ini adalah data primer dengan menggunakan metode wawancara. Pengolahan dan analisis data dilakukan secara deskriptif dan inferensia (uji beda t dan uji regresi linear berganda). Hasil penelitian menunjukkan bahwa kontribusi ekonomi yang dilakukan oleh istri nelayan lebih besar dibandingkan oleh istri buruh tani bawang pada saat musim melaut/panen. Tekanan ekonomi dan kesejahteraan keluarga yang dialami oleh keluarga nelayan dan keluarga buruh tani bawang baik pada musim melaut/panen maupun pada musim tidak melaut/paceklik termasuk kategori sedang. Hasil analisis menunjukkan bahwa jumlah anggota keluarga dan pedapatan per kapita memiliki pengaruh positif yang signifikan terhadap kesejahteraan keluarga. Sementara itu, tekanan ekonomi memiliki pengaruh negatif yang signifikan terhadap kesejahteraan keluarga.
\end{abstract}

Kata kunci: buruh tani bawang, keluarga nelayan, kesejahteraan keluarga, kontribusi ekonomi, tekanan ekonomi

\section{Women's Economic Contribution, Economic Pressure, and Family Welfare of Fisherman's and Onion Farm Laborer's Families}

\begin{abstract}
Most of farmers and fishermen in Indonesia have limitations in fulfill economic, social, and other standard needs. This limitation shows the low level of family well-being. This study was to analyze the characteristics of family, women's economic contributions, and economic pressures on family well-being of fisherman and onion farm laborers families. The location of the study was carried out at two locations, in Kali Adem Muara Angke and Losari Lor Village. This study involved 130 respondents (60 fisherman's wives and 70 onion farm laborer's wives). The data collected in this study are primary data with interview method. Data was analyzed with statistic descriptive and inferently (independent sample t test and multiple linear regression test). The results showed that the economic contribution made by the fishermen's family was greater than that of the onion farmer family. The economic pressure and family well-being experienced by the families of fishermen's and onion farm laborer's families both in the sea/harvest season and in the season does not go to sea/famine was medium category. Result found that number of family members and income per capita have a significant positive influence on family well-being. In addition, economic pressure variable has a significant negative influence on family well-being.
\end{abstract}

Keyword: economic contribution, economic pressure, family well-being, fisherman family, onion farm laborers

\section{PENDAHULUAN}

Kemiskinan adalah kondisi keterbatasan individu dalam memenuhi kebutuhan hidup secara layak yang terdiri atas keterbatasan dalam pendapatan, keterampilan, kondisi kesehatan, penguasaan aset ekonomi, ataupun akses informasi (Sunarti, 2012). Selain itu, kemiskinan juga merupakan salah satu isu strategis yang masih menjadi permasalahan nasional. Isu kemiskinan yang merupakan multidimensi ini menjadi isu sentral di Indonesia dan semakin menjadi perhatian berbagai unsur masyarakat (Kamaludin, 2004).

Masalah kemiskinan dapat menunjukkan tingkat kesejahteraan individu atau keluarga yang rendah (CPRC, 2009). Kemiskinan 
membuat anggota keluarga merasa tertekan secara ekonomi (Elder et al., 1992) yang kemudian berdampak pada kesejahteraan psikologis keluarga, perceraian, konflik antar anggota keluarga, kekerasan dalam rumah tangga, dan kenakalan remaja (Puspitawati, Herawati, \& Sarma, 2018). Peningkatan angka kemiskinan membuat keluarga melakukan strategi untuk mengatasinya, salah satunya kelompok perempuan yang bekerja di sektor publik dengan membuat usaha ekonomi.

Kelompok usaha ekonomi produktif perempuan ini dapat berkontribusi secara ekonomi untuk menambah pendapatan bagi keluarganya. Peran perempuan secara ekonomi adalah menambah penghasilan keluarga, karena itu penghasilan tambahan dari aktivitas ekonomi perempuan dapat membantu mengentaskan keluarga dari kemiskinan (Rahardjo, Puspitawati, \& Krisnatuti, 2015). Usaha ekonomi produktif perempuan ini juga merupakan upaya untuk meningkatkan pemenuhan hak ekonomi perempuan dalam keluarganya. Menurut Lasswell dan Lasswell (1987), kontribusi ekonomi perempuan dalam ekonomi keluarga akan menghasilkan peningkatan dalam keuangan keluarga, kepemilikan barang mewah, standar hidup yang lebih tinggi dengan pencapaian rasa aman yang lebih baik sehingga berdampak pada peningkatan status sosial keluarga. Menurut Belgum dan Chakrabortty (1995) aktivitas ekonomi perempuan memiliki kontribusi yang sangat penting dalam kelangsungan hidup dan kesejahteraan keluarga.

Kontribusi perempuan dalam keluarga baik untuk kegiatan rumah tangga maupun kegiatan ekonomi memiliki peran yang besar untuk menunjang pendapatan rumah tangga. Penghasilan tambahan dari aktivitas perempuan di sektor produktif diharapkan dapat membantu mengatasi masalah ekonomi keluarga. Peran perempuan dalam sektor domestik untuk mengelola sumberdaya keluarga yang dimilikinya diharapkan dapat mewujudkan kesejahteraan keluarga.

Hingga saat ini, sebagian penduduk Indonesia masih termasuk dalam kategori miskin. Sebagian besar jumlah penduduk miskin tersebut berada di wilayah perdesaan. Sebagian keluarga di wilayah perdesaan yang termasuk dalam kategori miskin merupakan keluarga yang bekerja sebagai petani. Data yang dipublikasikan oleh BPS (2017) menunjukkan bahwa jumlah penduduk miskin Kabupaten Brebes pada tahun 2017 sebanyak 343,46 ribu jiwa. Penduduk miskin di
Kabupaten Brebes didominasi oleh rumah tangga sebanyak 49,89 persen dengan penghasilan utama dalam bidang pertanian, termasuk juga di dalamnya adalah buruh tani. Salah satu kelompok keluarga yag termasuk dalam keluarga miskin di Kabupaten Brebes adalah buruh tani bawang merah. Kondisi ini dapat terjadi karena pendapatan keluarga tidak menentu bergantung pada musim panen. Hasil penelitian Aldila, Fariyanti, dan Tinaprilla (2015) menunjukkan bahwa upah kerja yang didasarkan pada musim panen bawang merah menjadikan pendapatan keluarga buruh tani bawang menjadi tidak menentu, mengingat bawang merah merupakan tanaman musiman yang hanya ditanam pada musim-musim tertentu.

Sebagian keluarga di wilayah perdesaan yang termasuk dalam kategori miskin juga merupakan keluarga yang bekerja sebagai nelayan. Jumlah penduduk miskin di Jakarta Utara pada tahun 2017 sebanyak 98,11 ribu jiwa (BPS, 2018). Penduduk miskin tersebut bekerja sebagai nelayan. Pendapatan dari keluarga nelayan juga tidak menentu. Penelitian Retnowati (2011) mengungkapkan pendapatan nelayan bergantung pada banyaknya hasil tangkapan yang dipengaruhi oleh musim dan cuaca, terbatasnya modal usaha, tekanan dari pemilik modal, minimnya sarana penunjang, buruknya mekanisme dan komunikasi yang terjalin, sistem bagi hasil yang tidak adil, serta perdagangan atau pelelangan ikan yang tidak transparan (dikuasai tengkulak) menyebabkan pendapatan keluarga nelayan tidak menentu.

Kondisi tersebut membuat keluarga buruh tani bawang dan nelayan dikategorikan dalam kelompok yang rentan terhadap kemiskinan. Pekerjaan yang tidak stabil, pengangguran, penurunan pendapatan, dan implikasi sosial (kurangnya ikatan sosial) menyebabkan munculnya tekanan ekonomi yang dirasakan oleh individu ataupun keluarga (Elder et al., 1992). Tekanan ekonomi didefinisikan sebagai ketidakmampuan keluarga untuk memenuhi kebutuhan seperti pangan, sandang, papan, kesehatan dan pendidikan (Mistry et al., 2008). Hasil penelitian Firdaus dan Sunarti (2009) menunjukkan bahwa semakin tinggi tekanan ekonomi yang dialami oleh keluarga maka semakin menurun tingkat kesejahteraan keluarga.

Kesejahteraan merupakan salah satu tujuan keluarga dalam menjalankan kehidupannya. Terdapat dua indikator dalam mengukur kesejahteraan keluarga yaitu kesejahteraan 
objektif dan subjektif (Netuveli \& Blane, 2008). Kesejahteraan objektif mengukur tingkat kesejahteraan aktual keluarga sedangkan kesejahteraan subjektif merupakan kepuasan kehidupan individu secara keseluruhan (Osborne, Simon, \& Collins 2003). Salah satu indikator untuk mengukur kesejahteraan keluarga adalah faktor ekonomi (Sunarti, 2006). Permasalahan ekonomi yang umum terjadi pada keluarga adalah ketidakmampuan keluarga dalam memenuhi kebutuhan, sehingga diperlukan adanya kontribusi istri untuk meningkatkan pendapatan keluarga. Kontribusi ekonomi istri memerlukan alokasi waktu produktif yang melibatkan peran produktif perempuan sehingga terjadi peran pencari nafkah ganda dalam keluarga atau dual earner families (Puspitawati, 2013). Oleh sebab itu, apabila keluarga dapat melakukan kontribusi ekonomi dengan optimal maka keluarga akan mendapatkan tambahan pendapatan sehingga tekanan ekonomi dapat teratasi serta meningkatkan kesejahteraan keluarga.

Penelitian mengenai kontribusi ekonomi perempuan, tekanan ekonomi, dan kesejahteraan keluarga nelayan dan buruh tani bawang menjadi penting dilakukan karena secara aktual, masih banyak penduduk Indonesia yang tergolong dalam kategori miskin dengan sebagian besar jumlah tersebut berada di perdesaan baik sebagai petani maupun nelayan (Pusat Data dan Sistem Informasi Pertanian Kementrian Pertanian, 2017). Penelitian ini akan menyajikan perbandingan kondisi keluarga berdasarkan jenis pekerjaan (keluarga nelayan dan keluarga buruh tani bawang merah) dan juga berdasarkan musim (musim melaut/panen dan musim tidak melaut/paceklik).

Berdasarkan paparan tersebut, penelitian ini bertujuan untuk menganalisis perbedaan kontribusi ekonomi perempuan, tekanan ekonomi dan kesejahteraan keluarga pada keluarga buruh tani dan nelayan berdasarkan musim. Penelitian ini jug menganalisis pengaruh kontribusi ekonomi perempuan dan tekanan ekonomi terhadap kesejahteraan keluarga pada keluarga buruh tani dan nelayan antar musim.

\section{METODE}

Penelitian ini menggunakan desain cross sectional study, dengan menetapkan keluarga nelayan dan buruh tani bawang yang dipilih secara purposive. Lokasi penelitian di Kali Adem Muara Angke Kelurahan Pluit,
Kecamatan Penjaringan, Kota Jakarta Utara dan Desa Losari Lor, Kabupaten Brebes, Provinsi Jawa Tengah. Pengambilan data penelitian dilakukan pada bulan Maret hingga April tahun 2018.

Populasi penelitian ini adalah keluarga yang suaminya bekerja sebagai nelayan dan bertempat tinggal di Kali Adem Muara Angke Kelurahan Pluit, Kecamatan Penjaringan, Kota Jakarta Utara dan keluarga yang istrinya bekerja sebagai buruh tani bawang di Desa Losari Lor, Kecamatan Losari, Kabupaten Brebes, Jawa Tengah. Contoh penelitian ini adalah perempuan yang bekerja dengan suami sebagai nelayan dan perempuan yang bekerja sebagai buruh tani bawang. Teknik penarikan sampel dilakukan secara purposive sampling. Sampel dipilih secara sengaja dengan kriteria perempuan yang bekerja dan berasal dari keluarga lengkap (memiliki suami), serta bertempat tinggal di Kali Adem Muara Angke dan Desa Losari Lor. Jumlah sampel adalah 130 orang, yang terdiri atas 60 keluarga nelayan dan 70 keluarga buruh tani bawang.

Data yang dikumpulkan dalam penelitian ini berupa data primer menggunakan teknik wawancara langsung dengan hasil yang diperoleh dari data istri. Semua pertanyaan variabel dalam kuesioner ditanyakan dalam dua periode waktu yaitu pada musim melaut/panen dan pada musim tidak melaut/paceklik. Data primer yang dikumpulkan yaitu karakteristik responden, karakteristik keluarga, kontribusi ekonomi perempuan, tekanan ekonomi, dan kesejahteraan keluarga. Karakteristik keluarga (usia, lama pendidikan, pendapatan, dan besar keluarga).

Variabel kontribusi ekonomi perempuan (istri) merupakan proporsi pendapatan perempuan (istri) yang ikut bekerja terhadap pendapatan total keluarga (Puspitasari et al., 2013). Kontribusi ekonomi perempuan (istri) dalam penelitian ini diukur dengan membandingkan upah istri (rupiah per bulan) dengan total pendapatan keluarga (rupiah per bulan), selanjutnya dikalikan 100 persen, masingmasing pendapatan istri dibedakan pada saat musim melaut/panen dan musim tidak melaut/paceklik.

Variabel tekanan ekonomi merupakan ketidakberdayaan keuangan yang dirasakan oleh keluarga dalam memenuhi kebutuhan keluarga, dilihat dari kondisi ekonomi yang mencakup indikator struktural kemiskinan (Conger et al., 1990). Tekanan ekonomi dalam penelitian ini terbagi menjadi dua yaitu tekanan 
ekonomi objektif dan tekanan ekonomi subjektif. Pengukuran tekanan ekonomi objektif mengacu konsep kesulitan ekonomi menurut Lorenz et al., (1994). Tekanan ekonomi objektif memiliki empat butir pernyataan yaitu pendapatan total keluarga, pengeluaran total keluarga, aset, dan hutang. Indikator tekanan ekonomi objektif terdiri atas pendapatan per kapita (tidak miskin= skor 3 ; miskin= skor 1 ), status pekerjaan suami (bekerja tetap $=$ skor 3 ; bekerja tidak tetap $=$ skor 2 ; tidak bekerja $=$ skor 1 ); rasio pendapatan dan pengeluaran (pendapatan lebih besar dari pengeluaran $=$ skor 3 ; pendapatan sama dengan pengeluaran $=$ skor 2; pengeluaran lebih besar dari pendapatan= skor 1); rasio hutang dan aset (tidak berhutang = skor 3; berhutang $<50$ persen aset= skor 2; berhutang $>50$ persen aset= skor 1 ), masingmasing pernyataan dibedakan pada saat musim melaut/panen dan musim tidak melaut/paceklik. Berdasarkan perhitungan skor tekanan ekonomi objektif diperoleh skor tekanan ekonomi objektif total. Tekanan ekonomi subjektif merupakan permasalahan keuangan keluarga dengan melihat bagaimana persepsi keluarga terhadap permasalahan keuangan yang dihadapi (Sunarti, Tati, Atat, Noorhaisma, \& Lembayung, 2005). Pengukuran tekanan ekonomi subjektif dengan menggunakan kuesioner yang dimodifikasi oleh peneliti dari Hilton dan Devall (1997). Kuesioner tekanan ekonomi subjektif terdiri dari 11 item pertanyaan. Kuesioner ini diukur dengan menggunakan skala likert (1-4), yaitu "Tidak pernah" diberikan skor 1, "Jarang" diberikan skor 2, "Cukup sering" diberikan skor 3, dan "Sering sekali" diberikan skor 4, masingmasing pernyataan dibedakan pada saat musim melaut/panen dan musim tidak melaut/paceklik. Perolehan skor maksimal 44 dan minimal 11. Nilai cronbach's alpha dari tekanan ekonomi subjektif sebesar 0,870. Tekanan ekonomi total merupakan komposit dari tekanan ekonomi obyektif dan subyektif.

Kesejahteraan keluarga didefinisikan sebagai seberapa jauh rasa kebahagiaan atau kesejahteraan dan kepuasan yang dialami (Park \& Shin, 2005). Kesejahteraan keluarga sering digambarkan dengan dimensi kesejahteraan keluarga subjektif dan kesejahteraan keluarga objektif (Netuveli \& Blane, 2008). Pengukuran kesejahteraan objektif keluarga dimodifikasi dari Delhey et al., (2001). Kuesioner ini terdiri atas 14 butir pernyataan dengan pilihan jawaban adalah tidak (0) dan ya (1). Perolehan skor maksimal adalah 14 dan minimal adalah 0 . Nilai Cronbach's alpha dari kesejahteraan objektif sebesar 0,738. Kesejahteraan subjektif keluarga merupakan bagaimana seseorang berpikir dan merasakan kepuasan, kebahagiaan, dan kesejahteraan psikologis (Tinkler \& Hicks, 2011). Kesejahteraan subjekif keluarga diukur menggunakan kuesioner yang dimodifikasi dari Dublin (2013). Kuesioner ini terdiri atas14 butir pernyataan. Kuesioner ini diukur menggunakan skala Likert, yaitu skor 1 untuk jawaban "Sangat Tidak Puas", skor 2 untuk jawaban "Tidak Puas", skor 3 untuk jawaban "Puas", dan skor 4 untuk jawaban "Sangat Puas", masingmasing pernyataan dibedakan pada saat musim melaut/panen dan musim tidak melaut/paceklik. Perolehan skor maksimal adalah 56 dan skor minimal adalah 14 . Nilai Cronbach's alpha dari kesejahteraan subjektif sebesar 0,777 .

Pengolahan data dilakukan dengan menggunakan program komputer. Pengolahan data dilakukan secara bertahap mulai dari data yang terkumpul diolah melalui proses editing, coding, scoring, entry data, cleaning data, dan analisis data. Analisis data yang digunakan dalam penelitian ini adalah analisis deskriptif, uji inferensia (uji multiple regresi) dan uji beda (independent sample T-test dan paired sample $T$-test). Cut off yang digunakan adalah rendah apabila skor yang diperoleh berada pada rentang 00,0-33,3, sedang apabila skor yang diperoleh berada pada rentang 33,4-66,6, dan tinggi apabila skor yang diperoleh berada pada rentang 66,7-100,0. Uji beda independent sample $T$-test digunakan untuk membedakan hasil pengolahan antarvariabel antara buruh tani bawang dan nelayan. Uji beda paired sample T-test digunakan untuk membedakan hasil pengolahan antarvariabel dan hasil analisis regresi pada musim melaut/panen dan musim tidak melaut/paceklik.

\section{HASIL}

\section{Karakteristik Keluarga}

Karakteristik keluarga yag diukur terdiri atas usia suami dan istri, pendidikan suami dan istri, besar keluarga suami dan istri, pendapatan keluarga, dan pengeluaran keluarga. Usia istri pada keluarga nelayan dan keluarga buruh tani bawang termasuk dalam kategori usia dewasa awal dengan rata-rata usia sebesar 38,82 tahun (keluarga nelayan) dan 40,83 tahun (keluarga buruh tani bawang). Usia suami pada keluarga nelayan terkategori dalam usia dewasa awal dengan rata-rata usia sebesar 42,27 tahun, sedangkan pada keluarga buruh tani bawang termasuk dalam kategori usia dewasa madya dengan rata-rata usia sebesar 45,21 tahun. 


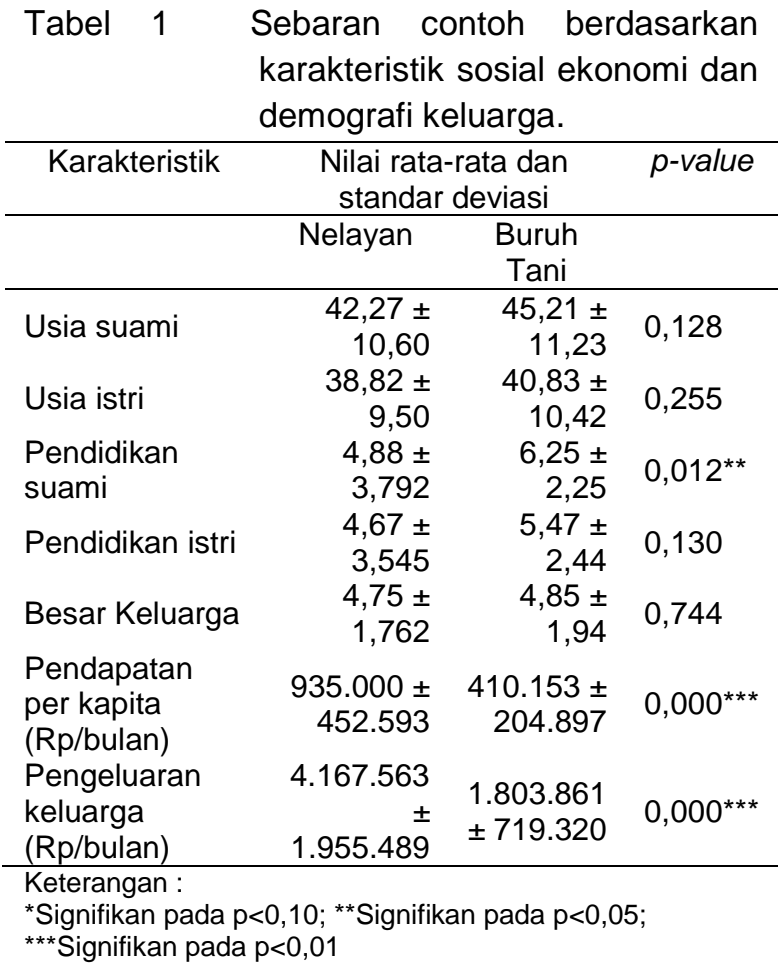

Untuk kategori pendidikan, persentase terbanyak istri dan suami pada keluarga nelayan dan keluarga buruh tani bawang yaitu Sekolah Dasar (SD). Hasil uji beda menunjukkan bahwa terdapat perbedaan yang signifikan ( $p$-value= 0,012 ) antara pendidikan suami keluarga nelayan dan buruh tani bawang yang mana rata-rata lama pendidikan suami pada keluarga buruh tani bawang lebih besar (6,2 tahun) daripada keluarga nelayan (4,8 tahun).

Lebih dari setengah keluarga baik pada keluarga nelayan maupun keluarga buruh tani bawang merah termasuk dalam kategori keluarga kecil. Rata-rata jumlah anggota keluarga pada keluarga buruh tani bawang lebih besar daripada keluarga nelayan, dengan rata-rata 4,85 orang. Penelitian ini juga mengumpulkan data pendaoatan keluarga. Hasil penelitian menunjukkan bahwa rata-rata jumlah pendapatan keluarga untuk keluarga nelayan adalag Rp935.000,00/kapita/bulan, sedangkan pada keluarga buruh tani bawang merah adalah Rp410.153,00/kapita/bulan. Pendapatan keluarga antara keluarga nelayan dan keluarga buruh tani bawang merah berbeda signifikan. Rata-rata pendapatan keluarga nelayan lebih besar daripada rata-rata pendapatan keluarga buruh tani bawang merah. Keluarga nelayan juga memiliki ratarata pengeluaran yang lebih besar (Rp4.167.563,00) dibandingkan dengan keluarga buruh tani bawang merah (Rp1.803.861,00).

\section{Kontribusi Ekonomi Perempuan terhadap Pendapatan Keluarga Buruh dan Nelayan}

Kontribusi ekonomi yang diberikan oleh istri dari keluarga nelayan diperoleh dari hasil bekerja sebagai penyortir ikan, pencari rumput laut, pencari kerang, pengolahan ikan asin, buruh pabrik pengolahan ikan, serta berdagang. Sementara itu, kontribusi ekonomi yang diberikan oleh istri keluarga buruh tani bawang diperoleh dengan menjadi buruh tani bawang.

Keluarga Nelayan dan Buruh Tani. Hasil penelitian yang disajikan pada Tabel 2 menunjukan bahwa kontribusi ekonomi total keluarga nelayan dan buruh tani. Istri berkontribusi terhadap pendapatan keluarga dengan rata-rata sebesar Rp939.308,00 per bulan. Kontribusi tersebut menyumbang ratarata 32,90 persen pada musim melaut/panen terhadap pendapatan keluarga. Pada musim tidak melaut/paceklik rata-rata pendapatan istri sebesar Rp600.654,00. Kontribusi tersebut menyumbang rata-rata 48,80 persen terhadap pendapatan keluarga.

Keluarga Buruh Tani Bawang. Hasil menunjukkan kontribusi ekonomi perempuan (istri) buruh tani bawang dimana istri berkontribusi terhadap pendapatan keluarga dengan rata-rata sebesar Rp505.714,00 per bulan. Kontribusi ekonomi perempuan tersebut menyumbang rata-rata 35,85 persen pada musim panen terhadap pendapatan keluarga buruh tani bawang. Pada musim paceklik pendapatan istri turun dengan rata-rata Rp59.285,00 per bulan. Kontribusi tersebut menyumbang rata-rata 6,15 persen pada musim paceklik terhadap pendapatan keluarga buruh tani bawang.

Keluarga Nelayan. Penelitian menggambarkan pada keluarga nelayan menunjukkan bahwa istri berkontribusi terhadap pendapatan keluarga dengan rata-rata sebesar Rp1.445.167,00 per bulan. Kontribusi ekonomi perempuan tersebut menyumbang rata-rata 31,80 persen pada musim melaut terhadap pendapatan keluarga nelayan. Pada musim tidak melaut istri berkontribusi besar terhadap pendapatan keluarga dengan rata-rata sebesar Rp1.232.250,00 per bulan. Kontribusi ekonomi perempuan tersebut menyumbang rata-rata 79,90 persen terhadap pendapatan keluarga nelayan. Rata-rata kontribusi ekonomi perempuan pada keluarga nelayan lebih tinggi dari suami saat musim tidak melaut. 
Tabel 2 Rata-rata kontribusi ekonomi perempuan terhadap pendapatan keluarga antar musim dan uji beda.

\begin{tabular}{|c|c|c|c|c|c|c|}
\hline \multirow[b]{2}{*}{$\begin{array}{l}\text { Kontribusi } \\
\text { (Rp/bulan) }\end{array}$} & \multicolumn{2}{|c|}{ Musim Melaut/Panen } & \multicolumn{2}{|c|}{ Musim tidak Melaut/Paceklik } & \multicolumn{2}{|c|}{$\begin{array}{c}\text { Uji Beda antar } \\
\text { Musim }\end{array}$} \\
\hline & $\begin{array}{c}\text { Rata-rata } \\
\text { pendapatan } \\
\text { (Rp) }\end{array}$ & $\begin{array}{c}\text { Kontribusi } \\
\text { pendapatan (\%) }\end{array}$ & $\begin{array}{c}\text { Rata-rata } \\
\text { pendapatan } \\
\text { (Rp) }\end{array}$ & $\begin{array}{c}\text { Kontribusi } \\
\text { pendapatan (\%) }\end{array}$ & $\mathrm{t}$ & $p$-value \\
\hline \multicolumn{7}{|c|}{ Keluarga Buruh Tani } \\
\hline Suami & 905.000 & 64,15 & 905.000 & 93,85 & 0 & 0 \\
\hline Istri & 505.714 & 35,85 & 59.285 & 6,15 & 17.617 & $0,000^{* * *}$ \\
\hline Total & 1.410 .714 & 100,00 & 964.285 & 100,00 & 17.617 & $0,000^{* * *}$ \\
\hline \multicolumn{7}{|c|}{ Keluarga Nelayan } \\
\hline Suami & 3.094 .167 & 68,20 & 309.417 & 20,10 & 12.482 & $0,000^{* * *}$ \\
\hline Istri & 1.445 .167 & 31,80 & 1.232 .250 & 79,90 & 6.993 & $0,000^{\star * *}$ \\
\hline Total & 4.539 .334 & 100,00 & 1.541 .667 & 100,00 & 13.751 & $0,000^{* * *}$ \\
\hline \multicolumn{7}{|c|}{ Keluarga Buruh Tani dan Nelayan } \\
\hline Suami & 1.915 .385 & 67,10 & 630.115 & 51,20 & 8.057 & $0,000^{* * *}$ \\
\hline Istri & 939.308 & 32,90 & 600.654 & 48,80 & 15.366 & $0,000^{\star * \star}$ \\
\hline Total & 2.854 .693 & 100,00 & 1.230 .769 & 100,00 & 10.765 & $0,000^{* * *}$ \\
\hline
\end{tabular}

Secara keseluruhan, kontribusi ekonomi perempuan menunjukkan perbedaan yang signifikan ( $p$-value $=0,005)$ antara musim panen dan musim paceklik dengan rata-rata 32,90 persen pada musim panen dan 48,80 persen pada musim paceklik. Menarik untuk dicermati adanya keunikan perbedaan kontribusi antar musim antara perempuan pada keluarga buruh tani dan nelayan. Kontribusi ekonomi perempuan pada keluarga buruh tani secara signifikan lebih besar pada musim panen dengan rata-rata 35,85 persen dibandingkan dengan musim paceklik yang rata-ratanya hanya 6,15 persen. Adapun kontribusi ekonomi perempuan pada keluarga nelayan secara signifikan lebih besar pada musim pacekli dengan rata-rata 79,90 persen dibandingkan dengan musim panen dengan rata-rata 31,80 persen.

\section{Tekanan Ekonomi pada Keluarga Buruh Tani Bawang dan Nelayan}

Tekanan ekonomi dalam penelitian ini dibagi menjadi dua yaitu tekanan ekonomi objektif dan tekanan ekonomi subjektif. Hasil penelitian mengenai tekanan ekonomi objektif disajikan pada Tabel 3. Sebanyak $(74,3 \%)$ keluarga buruh tani mengalami tekanan ekonomi objektif pada kategori rendah pada musim melaut/panen. Akan tetapi, pada musim tidak melaut/paceklik keluarga buruh tani mengalami tekanan ekonomi objektif kategori sedang $(51,4 \%)$. Hasil tersebut mempunyai persamaan pada keluarga nelayan, dimana pada saat musim melaut/panen keluarga nelayan mengalami tekanan ekonomi kategori rendah $(78,3 \%)$ dan pada musim tidak melaut/paceklik berada pada kategori sedang (63,3\%). Hasil penelitian menunjukkan tekanan ekonomi objektif keluarga buruh tani yang tidak berbeda secara signifikan ( $p$-value $>0,005)$ antara musim panen dan musim paceklik. Begitu pula pada keluarga nelayan yang tidak terdapat perbedaan yang signifikan ( $p$-value $>0,005)$ antara musim melaut/panen dan musim tidak melalut/paceklik. Dengan demikian tekanan ekonomi obyektif keluarga baik buruh tani maupun nelayan lebih tinggi tidak terdapat perbedaan antar musim.

Hasil penelitian mengenai tekanan ekonomi subjektif disajikan pada Tabel 3. Penelitian menggambarkan bahwa sebanyak 88,6 persen keluarga buruh tani dan sebanyak 51,7 persen keluarga nelayan mengalami tekanan ekonomi subjektif kategori rendah pada musim melaut/panen. Hasil tersebut mengalami perbedaan dimana pada musim tidak melaut/paceklik sebanyak 68,6 keluarga buruh tani mengalami tekanan ekonomi subjektif kategori rendah. Sebanyak 63,3 persen keluarga nelayan pada musim tidak melaut/paceklik mengalami tekanan ekonomi subjektif kategori sedang. Penelitian menunjukkan tekanan ekonomi subyektif keluarga buruh tani terdapat perbedaan yang signifikan $(p$-value $=0,005)$ antara musim panen dan musim paceklik dengan rata-rata 38,78 pada musim panen dan 48,28 pada musim paceklik. Begitu pula dengan keluarga nelayan, yaitu terdapat perbedaan yang signifikan ( $p$ value $=0,005$ ) antara musim melaut/panen dan musim tidak melalut/paceklik dengan rata-rata 48,28 pada musim melaut/panen dan 58,28 pada musim tidak melalut/paceklik. Dengan demikian tekanan ekonomi subyektif keluarga baik buruh tani maupun nelayan lebih tinggi pada musim paceklik dibandingkan dengan musim panen. 
Tabel 3 Kategori dan rata-rata tekanan ekonomi keluarga antar musim dan uji beda

\begin{tabular}{|c|c|c|c|c|c|c|c|c|c|c|}
\hline \multirow{3}{*}{ TE } & \multicolumn{3}{|c|}{$\mathrm{MM} / \mathrm{P}$} & \multirow{3}{*}{$\begin{array}{c}\text { Rata- } \\
\text { rata }\end{array}$} & \multicolumn{3}{|c|}{ MTM/Paceklik } & \multirow{3}{*}{$\begin{array}{c}\text { Rata- } \\
\text { rata }\end{array}$} & \multicolumn{2}{|c|}{ Uji beda } \\
\hline & Rendah & Sedang & Tinggi & & Rendah & Sedang & Tinggi & & $\mathrm{T}$ & $p$-value \\
\hline & $(\%)$ & $(\%)$ & $(\%)$ & & $(\%)$ & $(\%)$ & $(\%)$ & & & \\
\hline \multicolumn{11}{|c|}{ Keluarga Buruh Tani } \\
\hline TEO & 74,3 & 24,3 & 1,4 & 31,32 & 47,1 & 51,4 & 1,4 & 51,60 & -1.181 & 0,240 \\
\hline TES & 88,6 & 11,4 & 0,0 & 38,78 & 68,6 & 31,4 & 0,0 & 48,28 & 4.150 & $0,000^{* \pi *}$ \\
\hline TET & 81,4 & 18,6 & 0,0 & 38,05 & 51,5 & 48,5 & 0,0 & 43,50 & 0.858 & 0,392 \\
\hline \multicolumn{11}{|c|}{ Keluarga Nelayan } \\
\hline TEO & 78,3 & 20,0 & 1,7 & 32,29 & 36,7 & 63,3 & 0,0 & 58,12 & -1.174 & 0,242 \\
\hline TES & 51,7 & 45,0 & 3,3 & 48,28 & 36,7 & 63,3 & 0,0 & 58,28 & 4.279 & $0,000^{* \star \star *}$ \\
\hline TET & 76,7 & 23,3 & 0,0 & 40,28 & 26,7 & 73,3 & 0,0 & 51,81 & 0.860 & 0,391 \\
\hline \multicolumn{11}{|c|}{ Keluarga Buruh Tani dan Nelayan } \\
\hline TEO & 76,2 & 22,3 & 1,5 & 35,00 & 42,3 & 56,9 & 0,8 & 54,61 & -9.476 & 0,000 \\
\hline TES & 71,5 & 26,9 & 1,5 & 43,17 & 53,8 & 46,2 & 0,0 & 47,34 & -7.698 & $0,000^{\star \pi}$ \\
\hline TET & 79,1 & 20,9 & 0,0 & 39,08 & 41,5 & 58,5 & 0,0 & 50,97 & -10.630 & $0,000^{\pi \times \pi}$ \\
\hline
\end{tabular}

Keterangan: TEO: Tekanan Ekonomi Objektif; TES: Tekanan Ekonomi Subjektif; TET: Tekanan Ekonomi Total

${ }^{*}$ Signifikan pada $p<0,10$; ${ }^{* *}$ Signifikan pada $p<0,05$; ${ }^{* *}$ Signifikan pada $p<0,01$

Secara keseluruhan, tekanan ekonomi pada keluarga nelayan dan buruh tani pada musim melaut/panen berada pada kategori rendah $(79,1 \%)$ sedangkan pada musim tidak melaut/paceklik berada pada kategori sedang $(58,5 \%)$. Hasil penelitian menunjukkan bahwa keluarga buruh tani mengalami tekanan ekonomi kategori rendah baik pada musim melaut/panen dan musim tidak melaut/paceklik. Hasil tersebut berbeda dengan keluarga nelayan yang mengalami tekanan ekonomi kategori rendah $(76,7 \%)$ pada musim melaut/panen dan kategori sedang (73,3\%) pada musim tidak melaut/paceklik. Secara keseluruhan, tekanan ekonomi total menunjukkan perbedaan yang signifikan ( $p$ value $=0,005$ ) antara musim panen dan musim paceklik dengan rata-rata 39,08 pada musim panen dan 50,97 pada musim paceklik. Dengan demikian, tekanan ekonomi total keluarga baik buruh tani maupun nelayan lebih tinggi pada musim paceklik dibandingkan dengan musim panen.

\section{Kesejahteraan Keluarga pada Keluarga Buruh Tani Bawang dan Nelayan}

50,47 pada musim melaut/panen dan 48,09 pada musim tidak melalut/paceklik.

Hasil penelitian mengenai kesejahteraan subjektif keluarga juga dapat dilihat pada Tabel 4. Kesejahteraan subyektif keluarga buruh tani berbeda signifikan ( $p$-value $=0,005)$ antara musim panen dan musim paceklik dengan ratarata sebesar 50,68 pada musim panen dan 47,00 pada musim paceklik. Begitu pula dengan keluarga nelayan, yaitu terdapat perbedaan yang signifikan ( $p$-value $=0,005)$ antara musim melaut/panen dan musim tidak melalut/paceklik dengan rata-rata 72,08 pada musim melaut/panen dan 69,28 pada musim tidak melalut/paceklik. Dengan demikian, kesejahteraan subyektif keluarga baik buruh tani maupun nelayan lebih tinggi pada musim panen dibandingkan dengan musim paceklik.

Secara keseluruhan, kesejahteraan keluarga buruh tani dan nelayan berbeda signifikan ( $p$ value $=0,005$ ) antara musim panen dan musim paceklik dengan rata-rata 58,19 pada musim panen dan 56,11 pada musim paceklik (Tabel 4). Adapun secara parsial, terdapat perbedaan yang signifikan $(p$-value $=0,005)$ pada keluarga buruh tani antara musim panen dan musim paceklik dengan rata-rata 55,54 pada musim panen dan 53,91 pada musim paceklik. Demikian pula pada keluarga nelayan, hasil penelitian memperlihatkan bahwa perbedaan kesejahteraan secara signifikan ( $p$ value $=0,004)$ pada saat musim melaut/panen dan tidak melaut/paceklik dengan rata-rata 61,27 pada musim panen dan 58,91 pada musim paceklik. Dengan demikian, kesejahteraan total keluarga baik buruh tani maupun nelayan lebih tinggi pada musim papen dibandingkan dengan musim paceklik. 
Tabel 4 Kategori dan rata-rata kesejahteraan keluarga antarmusim dan uji beda

\begin{tabular}{|c|c|c|c|c|c|c|c|c|c|c|}
\hline \multirow{3}{*}{ KSK } & \multicolumn{3}{|c|}{ MM/Panen } & \multirow{3}{*}{ Rata-rata } & \multicolumn{3}{|c|}{ MTM/Paceklik } & \multirow{3}{*}{ Rata-rata } & \multicolumn{2}{|c|}{ Uji beda } \\
\hline & Rendah & Sedang & Tinggi & & Rendah & Sedang & Tinggi & & $\mathrm{t}$ & $p$-value \\
\hline & $(\%)$ & $(\%)$ & $(\%)$ & & $(\%)$ & $(\%)$ & $(\%)$ & & & \\
\hline \multicolumn{11}{|c|}{ Buruh Tani } \\
\hline KSO & 27,1 & 55,7 & 17,1 & 60,40 & 27,1 & 55,7 & 17,1 & 60,81 & -3.532 & $0,001^{n}$ \\
\hline KSS & 55,7 & 44,3 & 0,0 & 50,68 & 75,7 & 24,3 & 0,0 & 47,00 & 11.21 & $0,000^{* * \star}$ \\
\hline KSK & 37,1 & 61,4 & 1,4 & 55,54 & 44,3 & 54,3 & 1,4 & 53,91 & 2. 86 & $0,005^{* \star}$ \\
\hline \multicolumn{11}{|c|}{ Nelayan } \\
\hline KSO & 48,3 & 46,7 & 5,0 & 50,47 & 55,0 & 43,3 & 1,7 & 48,09 & -3.588 & 0,000 \\
\hline KSS & 6,7 & 58,3 & 35,0 & 72,08 & 8,3 & 60,0 & 31,7 & 69,28 & 11.67 & $0,000^{\pi \times \pi}$ \\
\hline KSK & 23,3 & 43,3 & 1,7 & 61,27 & 26,7 & 70,0 & 3,3 & 58,91 & 2.93 & $0,004^{\star \pi}$ \\
\hline \multicolumn{11}{|c|}{ Kesejahteraan Keluarga Total } \\
\hline $\mathrm{KSO}$ & 36,9 & 51,5 & 11,5 & 55,82 & 40,0 & 50,0 & 10,0 & 54,94 & 3.396 & $0,001_{x \times \pi}^{\pi}$ \\
\hline KSS & 33,1 & 50,8 & 16,2 & 60,55 & 44,6 & 40,8 & 14,6 & 57,28 & 7.483 & $0,000_{\pi \times \pi}^{\pi \times \pi}$ \\
\hline KSK & 30,8 & 63,8 & 5,4 & 58,19 & 36,2 & 61,5 & 2,3 & 56,11 & 8.856 & $0,000^{\star \pi}$ \\
\hline
\end{tabular}

\section{Pengaruh Karakteristik Keluarga, Kontribusi Ekonomi, dan Tekanan Ekonomi terhadap Kesejahteraan Keluarga}

Uji regresi yang digunakan pada penelitian ini adalah multiple regression yang terdiri atas dua model yaitu uji regresi pada musim melaut/ panen dan pada musim tidak melaut/paceklik. Model yang disusun pada musim melaut/panen memiliki nilai Adjusted $R$ Square sebesar 0,305 signifikan (sig=0,000). Artinya, model yang disusun hanya mampu menganalisis 30,50 persen pengaruh karateristik keluarga, kontribusi ekonomi, serta tekanan ekonomi terhadap kesejahteraan keluarga. Sisanya, sebesar 69,50 persen diduga dipengaruhi oleh variabel lain yang tidak diteliti dalam penelitian ini.

Hasil penelitian pada musim melaut/panen menunjukkan bahwa jumlah anggota keluarga $(B=0,823 ; \quad$ sig $=0,081)$ berpengaruh positif signifikan terhadap kesejahteraan keluarga. Hasil ini mengindikasikan bahwa penambahan jumlah anggota keluarga pada musim melaut/ panen mampu meningkatkan kesejahteraan keluarga. Pendapatan keluarga per kapita per bulan $(B=1,22 E-5 ; \quad$ sig $=0,000)$ berpengaruh positif signifikan terhadap kesejahteraan keluarga. Pertambahan pendapatan keluarga per kapita per bulan dapat meningkatkan kesejahteraan keluarga. Sementara itu, tekanan ekonomi keluarga $(B=-0,260 ; \quad$ sig $=0,000)$ berpengaruh signifikan negatif terhadap kesejahteraan keluarga. Hasil ini menunjukkan bahwa tekanan ekonomi yang semakin besar pada musim melaut/panen dapat menurunkan kesejahteraan keluarga.

Hasil uji regresi pada musim tidak melaut/paceklik menunjukkan nilai Adjusted $R$
Sqare sebesar 0,310 (sig=0,000). Hal tersebut menunjukkan bahwa variabel bebas dalam penelitian ini seperti usia istri, pendidikan istri, penghasilan istri, usia suami, pendidikan suami, penghasilan suami, jumlah anggota keluarga, pendapatan per kapita, kontribusi ekonomi, dan tekanan ekonomi memberi pengaruh sebanyak 31,00 persen terhadap kesejahteraan keluarga, sementara sisanya sebanyak 69,00 persen dipengaruhi oleh faktor lain yang tidak diteliti. Hasil penelitian menunjukkan bahwa jumlah anggota keluarga $(B=0,814$; sig $=0,088)$ berpengaruh positif signifikan terhadap kesejahteraan keluarga. Hasil ini mengindikasikan bahwa penambahan jumlah anggota keluarga pada musim tidak melaut/panen mampu meningkatkan kesejahteraan keluarga. Pendapatan keluarga per kapita per bulan ( $B=1,298 E-5$; sig=0,000) berpengaruh positif signifikan terhadap kesejahteraan keluarga. Pertambahan pendapatan keluarga per kapita per bulan dapat meningkatkan kesejahteraan keluarga. Sementara itu, tekanan ekonomi keluarga $(B=-$ 0,291; sig=0,000) berpengaruh negatif signifikan terhadap kesejahteraan keluarga. Hasil ini menunjukkan bahwa tekanan ekonomi yang semakin besar pada musim tidak melaut/ paceklik dapat menurunkan kesejahteraan keluarga.

Dengan demikian secara garis besar dapat dikatakan bahwa terdapat kesamaan faktorfaktor yang memengaruhi kesejahteraan keluarga total pada musim melaut/panen maupun musim tidak melaut/paceklik dengan derajat yang tertinggi sampai yang terendah berturut-turut adalah semakin tingginya pendapatan per kapita, semakin rendah tekanan ekonomi keluarga dan semakin banyaknya jumlah anggota keluarga. 
Tabel 5 Hasil uji pengaruh karakteristik keluarga, kontribusi ekonomi, dan tekanan ekonomi terhadap kesejahteraan keluarga total pada musim melaut/panen dan pada musim tidak melaut/paceklik

\begin{tabular}{lrrrrrr}
\hline \multirow{2}{*}{ Variabel } & \multicolumn{3}{c}{ Musim } & Melaut/Panen & \multicolumn{3}{c}{ Musim Tidak Melaut/Paceklik } \\
\cline { 2 - 7 } & \multicolumn{1}{c}{$\mathrm{B}$} & \multicolumn{1}{c}{ Sig } & \multicolumn{1}{c}{$\mathrm{B}$} & \multicolumn{1}{c}{$\beta$} & \multicolumn{1}{c}{ Sig } \\
\hline a & 55,142 & - & 0,000 & 57,146 & - & 0,000 \\
Pendidikan Istri (tahun) & 0,030 & 0,008 & 0,917 & 0,117 & 0,031 & 0,681 \\
Jumlah anggota keluarga (orang) & 0,823 & 0,133 & $0,081^{*}$ & 0,814 & 0,132 & $0,088^{*}$ \\
Pendapatan (Rp/kapita/bulan) & $1,122 \mathrm{E}-5$ & 0,442 & $0,000^{* * *}$ & $1,298 \mathrm{E}-5$ & 0,513 & $0,000^{* * *}$ \\
Kontribusi Ekonomi perempuan (persen) & 0,060 & 0,110 & 0,176 & 0,010 & 0,032 & 0,773 \\
Tekanan ekonomi total (indeks) & $-0,260$ & $-0,334$ & $0,000^{* * *}$ & $-0,291$ & $-0,333$ & $0,000^{* * *}$ \\
\hline F & & & 12,333 & & & 12,598 \\
Adjusted R-Square & & & 0,305 & & & 0,310 \\
Sig. & & & 0,000 & & & 0,000 \\
\hline
\end{tabular}

Keterangan: *Signifikan pada $p<0,10 ;{ }^{* *}$ Signifikan pada $p<0,05 ;{ }^{* *}$ Signifikan pada $p<0,01$

\section{PEMBAHASAN}

Kesejahteraan keluarga menunjukkan seberapa jauh rasa kebahagiaan atau kesejahteraan dan kepuasan yang dialami oleh individu dan keluarga, kesejahteraan keluarga digambarkan dengan dimensi kesejahteraan keluarga subjektif dan kesejahteraan keluarga objektif (Park \& Shin, 2005; Netuveli \& Blane, 2008). Terdapat perbedaan dalam menganalisis kesejahteraan keluarga petani dan nelayan. Perbedaan kondisi demografi menjadi salah satu faktor pendukungnya. Keluarga petani memiliki sumber daya yang terkontrol, dengan lahan pertanian yang lebih mudah dijangkau, sebaliknya keluarga nelayan memiliki sumber daya yang open access, menjadikan keluarga nelayan memiliki risiko lebih tinggi (Satria, 2009). Hasil penelitian menunjukkan bahwa keluarga buruh tani bawang lebih sejahtera secara objektif dibandingkan keluarga nelayan. Akan tetapi, kesejahteraan subjektif dan kesejahteraan total keluarga nelayan lebih tinggi dibandingkan keluarga buruh tani bawang. Setiap orang memiliki penilaian terhadap tingkat kesejahteraan antara satu sama lain tidak sama. Sejahtera bagi seseorang belum tentu sama dengan yang lainnya. Hal ini dikarenakan setiap orang memiliki pengalaman dan tingkat kepuasan yang berbeda yang sangat bergantung pada kepribadian masing-masing individu terhadap tingkat kepuasan dan persepsi yang dimilikinya akibat dari pengalaman sebelumnya (Angur, Robin, \& Sudhir 2004).

Kemiskinan merupakan masalah yang sering dialami oleh keluarga, khususnya pada keluarga nelayan dan buruh tani. Keluarga nelayan dan buruh tani bawang memiliki potensi besar dalam permasalahan tekanan ekonomi (Sugiharto, 2014). Hasil penelitian menunjukkan adanya perbedaan yang siginifikan antara tekanan ekonomi keluarga nelayan dan keluarga buruh tani bawang, dimana keluarga nelayan lebih tertekan secara ekonomi dibandingkan keluarga buruh tani bawang. Satria (2009) menyebutkan bahwa perbedaan karakteristik demografi menjadikan permasalahan yang dialami oleh keluarga petani dan nelayan berbeda. Pada umumnya secara sosiologis, keluarga petani berbeda dengan keluarga nelayan. Keluarga petani menghadapi sumber daya yang terkontrol, yakni pengelolaan lahan untuk produksi suatu komoditas dengan output yang relatif bisa diprediksi. Produksi yang demikian memungkinkan tetapnya lokasi produksi sehingga menyebabkan mobilitas dan risiko rendah. Karakteristik tersebut berbeda sekali dengan nelayan, yang menghadapi sumber daya yang bersifat open access. Hal tersebut menyebabkan nelayan harus berpindah-pindah lokasi untuk memperoleh hasil maksimal. Dengan demikian, risiko menjadi sangat tinggi dan tidak pasti (Satria et al., 2015). Hasil penelitian Kumalasari, Herawati, dan Simanjuntak (2018) menyebutkan keluarga nelayan memiliki besaran pendapatan yang tidak tetap sehingga merasa kesulitan dalam mencukupi kebutuhan hidup sehari-hari. Permasalahan lain yang dihadapi oleh keluarga nelayan adalah nilai-nilai yang dianut dalam menjalani kehidupan sehari-hari didominasi oleh sikap pasrah dan sabar. Nilai tersebut mencerminkan kondisi keluarga yang statis sehingga usaha untuk mendapatkan kehidupan yang lebih baik relatif rendah.

Permasahan ekonomi yang terjadi pada keluarga nelayan dan buruh tani bawang membuat para perempuan (istri) merasa turun tangan untuk ikut bekerja. Meningkatnya partisipasi perempuan sebagai pekerja dapat meningkatkan pendapatan rumah tangga (Ministry of Health, Lobour \& Welfare, 2005). Hasil penelitian menunjukan bahwa terdapat perbedaan yang signifikan antara kontribusi 
ekonomi perempuan (istri) keluarga nelayan dan buruh tani, dimana istri buruh tani bawang berkontribusi lebih tinggi pada saat musim melaut/panen dibandingkan istri nelayan. Sebaliknya, pada musim tidak melaut/paceklik, kontribusi istri nelayan terhadap pendapatan keluarga lebih tinggi dibandingkan istri buruh tani bawang. Hasil tersebut sesuai dengan penelitian Ilma dan Muis (2015) yang menyebutkan bahwa besarnya kontribusi yang diberikan oleh buruh wanita terhadap pendapatan keluarga dilihat dari proporsi ratarata upah buruh wanita terhadap rata-rata pendapatan keluarga ternyata cukup besar yakni sebesar 11,23 sampai 52,32 persen. Kontribusi ekonomi tersebut akan menurun pada musim paceklik dikarenakan keterbatasan sumberdaya yang ada sehingga menyebabkan istri buruh tani bawang tidak bisa bekerja, lain halnya dengan istri nelayan pada saat musim tidak melaut kontribusi ekonomi yang dihasilkan lebih tinggi sebagai akibat keterbatasan suami dalam pendapatan sehingga memaksa para istri untuk lebih banyak berkontribusi dalam ekonomi. Hasil tersebut sesuai dengan penelitian Wawansyah, Gumilar, \& Taufiqurahman (2012) yang menyebutkan bahwa kontribusi pendapatan istri nelayan pada saat musim tidak melaut cukup tinggi yaitu sebesar 39,45 persen sampai 70,00 persen. Perempuan dari keluarga nelayan akan melakukan beberapa usaha yang dapat digunakan untuk menambah pendapatan keluarga melalui beberapa usaha yaitu mengolah ikan asin, mengolah kerupuk udang, mengolah terasi, dan mengolah rumput laut (Hidayah, Mahyudi, \& Mahreda 2014).

Hasil penelitian menunjukkan bahwa pendapatan per kapita memiliki pengaruh positif signifikan terhadap kesejahteraan keluarga. Kondisi ini disebabkan apabila keluarga memiliki pendapatan per kapita yang cukup dapat memenuhi kebutuhan anggota keluarga dan merasa bahagia sehingga dapat mengoptimalkan kesejahteraan keluarga. Hasil ini sejalan dengan penelitian (Muflikhati Hartoyo, Sumarwan, Fahrudin, \& Puspitawati, 2016) yang menyebutkan bahwa tingkat pendapatan yang tinggi akan memberi peluang lebih besar untuk membeli kebutuhan pangan dan nonpangan yang lebih baik dari segi kuantitas maupun kualitas. Pendapatan berpengaruh besar terhadap kebahagiaan individu karena pendapatan memberikan kontribusi yang signifikan terhadap pemenuhan kebutuhan-kebutuhan dasar, seperti makanan, sandang, dan papan. Hal ini sejalan dengan penelitian Suryawati (2002) yang menyebutkan bahwa pendapatan akan memengaruhi aktivitas rumah tangga dalam upaya pemenuhan kebutuhan keluarga.

Penelitian menunjukkan bahwa tekanan ekonomi berpengaruh negatif signifikan terhadap kesejahteraan keluarga. Kondisi ini menunjukkan ketika keluarga mengalami tekanan ekonomi dalam hidupnya, maka keluarga merasa kurang bahagia dalam hidupnya serta tidak dapat mengoptimalkan kesejahteraan keluarga. Hasil tersebut sesuai dengan penelitian Elder (1992) dan Simanjuntak (2010) yang menyebutkan bahwa tekanan ekonomi berpengaruh negatif signifikan terhadap kesejahteraan keluarga, yaitu semakin rendah tekanan ekonomi semakin tinggi kesejahteraan keluarga yang dirasakan keluarga. Sunarti (2015) menjelaskan, berbagai kerentanan keluarga merupakan konsekuensi dari ketidakmampuan dalam membangun keterikatan, kepemilikan rumah, dan tekanan ekonomi. Feil (2012) memaparkan bahwa tekanan ekonomi keluarga dapat berasal dari kehilangan pekerjaan, kehilangan rumah, dan perubahan kondisi finansial keluarga.

Di samping itu, penelitian ini juga menemukan bahwa jumlah anggota keluarga berpengaruh positif signifikan terhadap kesejahteraan keluarga. Kondisi tersebut menggambarkan bahwa apabila keluarga mempunyai anggota yang banyak, income (pendapatan keluarga) yang diterima oleh keluarga akan semakin banyak sehingga dapat mengoptimalkan kesejahteraan dalam keluarga. Hasil tersebut berkebalikan dengan penelitian Muflikahati et al. (2010) yang menyebutkan bahwa jumlah anggota keluarga yang lebih sedikit memiliki peluang untuk lebih sejahtera. Keluarga dengan anggota yang lebih kecil akan mengurangi beban keluarga dalam memenuhi kebutuhannya, sehingga tingkat kesejahteraan keluarga semakin meningkat.

\section{SIMPULAN DAN SARAN}

Pendidikan, pendapatan, dan pengeluaran keluarga antara keluarga nelayan dan buruh tani bawang berbeda signifikan. Keluarga buruh tani bawang menempuh pendidikan yang lebih lama dibandingkan dengan keluarga nelayan. Keluarga nelayan memiliki pendapatan dan pengeluaran keluarga yang lebih besar dibandingkan dengan keluarga buruh tani bawang. Hasil penelitian menunjukkan bahwa kontribusi ekonomi yang dilakukan oleh istri nelayan lebih besar dibandingkan oleh istri buruh tani bawang pada saat musim melaut/panen. Tekanan ekonomi dan 
kesejahteraan keluarga yang dialami oleh keluarga nelayan dan keluarga buruh tani bawang baik pada musim melaut/panen maupun pada musim tidak melaut/paceklik termasuk kategori sedang. Hasil analisis menunjukkan bahwa jumlah anggota keluarga dan pedapatan per kapita memiliki pengaruh positif yang signifikan terhadap kesejahteraan keluarga. Sementara itu, tekanan ekonomi memiliki pengaruh negatif yang signifikan terhadap kesejahteraan keluarga.

Berdasarkan temuan penelitian, keluarga buruh tani bawang dan keluarga nelayan diharapkan mampu mengembangkan potensi dalam meningkatkan pendapatan keluarga melalui mencari pekerjaan lain pada waktu musim tidak melaut/paceklik, menambah anggota keluarga yang bekerja, serta mengurangi pengeluaran khususnya pada keluarga nelayan yang lebih boros dalam pengeluaran. Selain itu, keluarga diharapkan juga untuk melakukan usaha menabung dengan cara menyisihkan pendapatan yang diperoleh sebagai antisipasi keuangan pada musim tidak melaut/paceklik.

\section{DAFTAR PUSTAKA}

[BPS] Badan Pusat Statistik. (2017). Garis Kemiskinan Menurut Provinsi 2013-2017. Diambil dari: https://www.bps.go.id/linkTableDinamis/vie w/id/1120. [diunduh 30 Maret 2018].

[BPS] Badan Pusat Statistik. (2018). Tingkat Kemiskinan dan Ketimpangan di DKI Jakarta, Maret 2018. Diambil dari: https://jakarta.bps.go.id/pressrelease/2018 /07/16/321/tingkat-kemiskinan-danketimpangan-di-dki-jakarta-maret-2018.html. [diunduh 30 Oktober 2018].

[CPRC] Chronic Poverty Research Center. (2009). Escaping poverty traps. The Chronic Poverty Report 2008-2009. Diambil dari: http://www.chronicpoverty.org. [diunduh 30 Januari 2018].

[KEMENTAN] Kementrian Pertanian. (2017). Statistik Pertanian 2017. Diambil dari: http://pangan.litbang.pertanian.go.id/files/S tatistik/StatistikPertanian2017.pdf. [diunduh 31 Desember 2018].

Aldila H.F., Fariyanti A., \& Tinaprilla, N. (2015). Analisis profitabilitas usaha tani bawang merah berdasarkan musim di tiga kabupaten sentra produksi di Indonesia. Social Economic and Agribusiness Journal. 11(2): 249-260. ISSN: 1829-9946.
Angur, M.G., Robin, W., \& Sudhir, G.A. (2004). Congruence among Objective and Subjective Quality-of-Life (QOL) Indicators. Journal Alliance of Business Research, 5(2):47-52.

Begum, A., \& Chakrabortty, K. (1995). Economic Contribution of Rural Women and Their Participation in The Household Decision Making Process in Bangladesh. Bangladesh Journal Agriculture Economics. XVIII, 1 : 51-69.

Conger, R.D., Elder Jr, G. H., Lorenz, F.O., Conger K.J., Simons, R. L., Whitbeck, L.B., \& Melby, J.N. (1990). Linking economic hardship to marital quality and instability. Journal of Marriage and the Family. 52(3): 643-656. Doi: 10.2307/352931.

Delhey, J., Böhnke, P., Habich, R., \& Zapf, W. (2001). The eromodule a new instrument for comparative welfare research. Social Structure and Social Reporting. 3(1): 119. ISSN:1615-7540.

Dublin. (2013). Quality of Life in Europe: Subjective Well-Being. Luxembourg: Publications Office of the European Union. ISBN: 978-92-8971-120-3. Doi: $10.2806 / 37878$.

Elder Jr, G.H., Conger, R.D., Foster, E.M., Ardelt, M. (1992). Families under economic pressure. Journal of Family Issues. 13(1): 5-37. Doi: 301/587-8202.

Falkingham, J,, \& Baschieri, A. (2009). Gender and poverty: how misleading is the unitary model of household resources? an illustration from Tajikistan. Global Social Policy, 9(1): 43-62. Doi: $10.1177 / 1468018108100397$.

Feil, J.K. (2012). Coping with economic stressors: religious and non-religious strategies for managing psychological distress.(Tesis). Minnesota State University, Mankato. Inggris

Firdaus, \& Sunarti, E. (2009). Hubungan antara tekanan ekonomi dan mekanisme koping dengan kesejahteraan keluarga pemetik teh. Jurnal IImu Keluarga dan Konsumen. 2(1): 21-31. Doi: http://dx.doi.org/10.24156/jikk.2009.2.1 .21 .

Hidayah, U.N., Mahyudi, I., Mahreda, E. S. (2014). Kontribusi dan peluang peningkatan pendapatan isteri nelayan terhadap pendapatan keluarga di 
Kecamatan Aluh-Aluh Kabupaten Banjar Kalimantan Selatan. Fish Scientiae Journal. 4(8): 128-137. Doi: http://dx.doi.org/10.20527/fs.v4i8.1125

Hilton, J.M., \& Devall, EL. (1997). The family economic strain scale: development and evaluation of the instrument with singleand two-parent families. Journal of Family and Economic Issues. 18(3):247-271. Doi: 10.1023/A:1024974829218.

Ilma, B., Muis A. (2015). Kontribusi wanita tani terhadao pendapatan rumah tangga petani kelapa sawit di Desa Kasaloang Kecamatan Bambaira Kabupaten Mamuju Utara. Jurnal Agrotekbis. 3(2): 231-239. ISSN: 2338-3011.

Kamaludin, S. (2014). Faktor-faktor yang mempengaruhi tingkat inflasi dan implikasinya terhadap investasi, kesempatan kerja, kemiskinan, dan kesejahteraan masyarakat di Indonesia. Jurnal Sosial Ekonomi Kelautan dan Perikanan. 9(2): 195-206.

Kumalasari, B., Herawati,T., Simanjuntak, M. (2018). Relasi gender, tekanan ekonomi, manajemen keuangan, strategi nafkah, dan kualitas hidup pada keluarga nelayan. Jurnal IImu Keluarga dan Konsumen. 11(2): $\quad 108-119 . \quad$ Doi: http://dx.doi.org/10.24156/jikk.2018.11.2.1 08.

Lasswell, M. E., \& Lasswell T. E., (1987). Marriage and the Family. California: Wadsworth Pub.

Lorenz, F.O., Conger, SD, Montague R. (1994). Doing worse and feeling worse; psychologycal consequences of economic hardship. Dalam: Conger DR, Elder GH, Lorenz FOJr, Simon RL, Whitbeck LB, editor. Families in Troubled Times: Adapting to Change Rural America. Ed ke8. New York: Aldine De Cruyter.

Ministry of Health, Labour, and Welfare. (2005). [White paper on women's labor: Fiscal year 2004]. Tokyo: Japan Institute of Workers Evolution.

Mistry, R.S., Lowe, E.D., Benner, A.D., \& Chien, N. (2008). Expanding the family economic stress model: Insight from a mixed-methods approach. Journal of Marriage and Family. 70(1), 196-209. Doi: 116.206.9.37.

Muflikhati, I., Hartoyo., Sumarwan, U., Fahrudin, A., \& Puspitawati, H. (2016). Kondisi Sosial ekonomi dan tingkat kesejahteraan keluarga: kasus di wilayah pesisir Jawa Barat. Jurnal IImu Keluarga dan Konsumen, 3(1), 1-10. Doi: http://dx.doi.org/10.24156/jikk.2010.3.1.1.

Netuveli, G., \& Blane, D. (2008). Quality of life in older ages. British Medical Buletin. 85:113-126. . ISSN: 0007-1420.

Osborne, J., Simon, S., \& Collins, S. (2003). Attitudes towards science: A review of the literature and its implications. International Journal of Science Education. 25(9):10491079.

Doi: 10.1080/0950069032000032199.

Park, C.M., \& Shin, D.C. (2005). Perceptions of life quality among the Korean mass public. Unraveling their dynamics and standards. Social Indicators Research. 70(3): 257-286. Doi: 10.1080/13552074.2015.1095550.

Puspitasari, N., Puspitawati, H., \& Herawati, T. (2013). Peran gender, kontribusi ekonomi perempuan, dan kesejahteraan keluarga petani holtikultura. Jurnal Ilmu Keluarga dan Konsumen. 6(1): 10-19. ISSN: 19076037.

Puspitawati, H., Herawati, T., \& Sarma, M. (2018). Reliabilitas dan Validitas Indikator Ketahanan Keluarga di Indonesia. Jurnal Kependudukan Indonesia. 13(1): 1-14. E-ISSN: 2502-853.

Puspitawati, H. (2013). Ketahanan dan Kesejahteraan Keluarga. Institut Pertanian Bogor.

Rahardjo, I.T., Puspitawati, H., Krisnatuti, D. (2015). Tekanan ekonomi, manejemen keuangan, dan kesejahteraan pada keluarga muda. Jurnal IImu Keluarga dan Konsumen. 8(1): 38-48. Doi: http://dx.doi.org/10.24156/jikk.2015.8.1.3 8.

Retnowati, E. (2011). Nelayan Indonesia dalam pusaran kemiskinan struktural (perspektif sosial, ekonomi, dan hukum). Perspektif. 16(3): 149-159.

Satria, A. (2009). Laut dan Pesisir untuk Kesejahteraan Masyarakat. Bogor: IPB Press.

Simanjuntak, M. (2010). Faktor-faktor yang mempengaruhi kesejahteraan keluarga dan prestasi belajar anak pada keluarga penerima Program Keluarga Harapan $(P K H)$.(Tesis). Institut Pertanian Bogor. Bogor, Indonesia. 
Sugiharto. (2014). Kerentanan, strategi nafkah, dan tingkat kesejahteraan keluarga petani di Kecamatan Playen, Kabupaten Gunung Kidul (Tesis). Institut Pertanian Bogor. Bogor, Indonesia.

Sunarti, E., Tati, Atat, S.N., Noorhaisma, R., \& Lembayung, D.P. (2005). Pengaruh tekanan ekonomi keluarga, dukungan sosial, kualitas perkawinan, pengasuhan, dan kecerdasan emosi anak terhadap prestasi belajar anak. Jurnal media gizi dan keluarga. 29(1): 34-40. ISSN 021169363.

Sunarti, E. (2006). Indikator Keluarga Sejahtera: Sejarah Pengembangan, Evaluasi, dan Keberlanjutannya. Naskah Akademik BKKBN. Bogor: Institut Pertanian Bogor.

(2012). Tekanan ekonomi dan kesejahteraan objektif keluarga di perdesaan dan perkotaan. Prosiding
Seminar Hasil-Hasil Penelitian IPB 2012. Bogor(ID): Institut Pertanian Bogor.

.(2015). Orasi Ilmiah Guru Besar IPB : Ketahanan Keluarga Indonesia dari Kebijakan dan Penelitian Menuju Tindakan. Bogor : IPB Press.

Suryawati. (2002). Alokasi pengeluaran untuk pendidikan anak pada keluarga ibu bekerja dan ibu tidak bekerja.(Tesis). Institut Pertanian Bogor. Bogor, Indonesia.

Tinkler, L., \& Hicks, S. (2011). Measuring subjective well-being and its potential role in policy: Prespectives from the UK office for national statistics. Social Indicators Research.114(1): 73-86. Doi: 10.1007/s11205-013-0384-x.

Wawansyah, H., Gumilar, I., Taufiqurahman, A. (2012). Kontribusi ekonomi produktif wanita nelayan terhadap pendapatan keluarga nelayan. Jurnal Perikanan dan Kelautan. 3(3): 95-106. ISSN: 2088-3137. 